\title{
Representations of the Concept of Pedagogical Supervision among Teachers
}

\author{
Ricardo Dias \\ Elementary School Teacher at Escola EB1/JI, and Researcher at \\ Education Sciences, Lisboa, Portugal. \\ Email: trucaricardo@gmail.com \\ Abílio Oliveira \\ Instituto Universitário de Lisboa (ISCTE-IUL), and Centro de Investigação em Sistemas \\ e Tecnologias de Informação Avançados (ADETTI-IUL), Lisboa, Portugal. \\ Author of several books (http://abiliooliveira. weebly.com/) \\ Email: olivirtual@gmail.com
}

\section{Doi:10.5901/jesr.2013.v3n7p190}

\section{Abstract}

\begin{abstract}
Considering teaching and education, the challenges we face daily are increasingly relevant, for all agents involved. Given the time that children spend in school, a good pedagogical relationship, between teachers and students, is very important in the development of children. So, teachers seek for strategies to make the process of teaching and learning more engaging for students, and more rewarding for themselves. This empirical study was developed within the scope of the theory of social representations (Moscovici, 1961/1976). We aimed to understand, first of all, the way how teachers ( $N=176)$, men and women, of the 1st and 2nd stages of basic education, in Portugal, represent the concept of pedagogical supervision, and also the way how the representations found can be related to the way they usually feel in classroom. The data was gathered using free associations of words, derived from open questions that were individually made, in an questionnaire (e.g., 'Pedagogical supervision makes me think of...'; or 'Pedagogical supervision makes me feel...'). Results were examined through the technique of factorial analysis of correspondences (FCA). Among the main findings, it was verified that, in general, the teachers of the 2nd stage feel more active than those of the 1st stage, linking the concept of pedagogical supervision with a helpful process that is led by someone with more experience and scientific knowledge. Women, compared to men, demonstrate more nervousness and anxiety, when confronted with pedagogical supervision, tending to anchor the supervision with the evaluation process that all teachers have throughout their career.
\end{abstract}

Keywords: pedagogical supervision, social representations, school, teachers, feelings

\section{Introduction}

The complexity of contemporary society and its rapid changes and movements, suggest that the role of training, especially in the field of pedagogy, should be viewed in a broadly sense, open and innovative, without restricting to a specific field, such as a educational or business issue (e.g., Simões and Ralha-Simões, 1997). Considering, the challenges we face daily, in the domains of teaching and education, are increasingly relevant, for all agents involved. Given the inclusion of this study in an educational context, the supervision appears as a process of teaching and learning, relative to the social representations of teachers of the 1st and 2nd stages, on the concept of pedagogical supervision.

Supervision is a concept that is linked to the orientation of pedagogical practice by someone that, in principle, is more experienced and informed (e.g., Alarcão, 2003), being strongly influenced by posture and vision of the supervisor, trying to see what happened before the process, what is happening in the present, and what can happen after the supervision process, with an intelligent attitude, responsible, empathic, peaceful and engaging, ie, the supervisor enters the process to understand it, from the outside and inside of it, to analyze it through his view, and see beyond it, based on a strategic thinking, in order to improve the learning and teaching process, and also contributing to a better relationship between the teacher and the students (Mintzberg, 1995; Alarcão, 2003).

As a teacher of 1 st and 2 nd stages of basic education, I realize that may be considered different representations of the concept of pedagogical supervision by teachers, related to different forms of how teachers develop their practices, 
which leads us to consider the importance of understanding the relationship between these same representations and the practices associated with them.

The process of supervision while training process is a constructive place where it is generated, moment by moment, a set of unpredictability, in which the representations are reconstructions of what is observed in the context of values, concepts and rules, and cannot be identified with the reproduction or copy of objects (Bidarra, 1986).

Given the time that children spend in school, a good pedagogical relationship, between teachers and students, is very important in the development of children. Thus, teachers seek for strategies to make the process of teaching and learning more engaging for students, and more rewarding for themselves. The pedagogical supervision may help the teachers and, indirectly, the students.

In this sense, when we focus on how teachers represent the pedagogical supervision, we intend, as a main goal, to understand the way of thinking and feeling, as well as the reactions, in relation to pedagogical supervision - and how these same representations may influence the process of teaching - raising a discussion that aimed at better training of teachers.

In social terms, we tend to understand and explain how the thoughts, feelings and behaviours of human beings are influenced by one another real, imaginary or implied (Allport, 1968; Leyens, 1979).

In studying representations, we study human beings, we reflect on what are human nature and the relationships that we hold between us (e.g., Oliveira, 2008; Pinho, 1993). In this study, we discuss relevant concepts, such as pedagogical supervision, school and education, in Portugal. We do not intend to suggest any model of supervision. However, we frame our results from the perspective of innovation and renewal of supervisory practices.

\section{Objectives}

We aimed to understand, first of all, the way how Portuguese teachers $(\mathrm{N}=176)$ of the 1st and 2nd stages of basic education, represent the concept of pedagogical supervision, and also the way how the representations found can be related to the way they usually feel in classroom.

\section{Method}

We had a sample of 176 Portuguese teachers (110 of the first stage and 66 of the second stage of basic education), of both sexes (24 men and 152 women). We developed a questionnaire consisting of open-ended questions in order to collect ideas, thoughts, symbols, feelings or emotions through free associations of words, to several questions, of which we highlight, in this work:

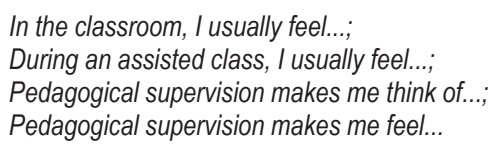

Teachers responded to these questions, without limitation, and spontaneously, through words or short phrases, maintaining the anonymity and confidentiality of their responses - all the answers, in each question, were reduced to simple words, with no categorization (e.g., Oliveira, 2004, 2008; Oliveira e Amaral, 2007).

The questionnaire also had some socio-demographic questions, such as genre/sex (men or women) and teaching cycle ( $1^{\text {st }}$ or $2^{\text {nd }}$ stage) - these corresponded to the independent variables.

Data was analyzed through the technique of factorial analysis of correspondences (FCA). The dimensions obtained through this technique, for each question, constituted the dependent variables.

\section{Results}

Most participants usually feel well in the classroom (the word cheerful is mentioned by almost $70 \%$ of teachers), however, they also feel tired. Reinforcing these feelings, seemingly ambivalent, we also find other words such as accomplished, frustrated, active and happiness (with frequencies around 40\%). Which leads us to think that being a teacher generates, on one hand, satisfaction with the work done, and by the like to teach, and secondly, a feeling of malaise, associated with some unattained objectives, with limitations and physical and psychological stress, inherent the activity of being a teacher, at contemporary schools. 
So, this is a good reason for a feeling of accomplishment, by what the teachers can achieve and are able to do with their students, also contributing for the development of the children. At the same time they may feel unsatisfied or frustrated, thinking that if they had better conditions, they probably could go further and help more all the children (cf. Table 1).

Table 1. 'In the classroom I usually feel...'

\begin{tabular}{l|c|c}
\hline Word & Frequency & $\%$ \\
\hline cheerful & 121 & $69 \%$ \\
tired & 98 & $56 \%$ \\
accomplished & 70 & $40 \%$ \\
frustrated & 67 & $38 \%$ \\
active & 59 & $34 \%$ \\
happy & 54 & $31 \%$ \\
resigned & 36 & $20 \%$ \\
unhappy & 28 & $16 \%$ \\
anxious & 25 & $14 \%$ \\
nervous & 24 & $14 \%$ \\
confident & 20 & $11 \%$ \\
careful & 18 & $10 \%$ \\
energetic & 17 & $10 \%$ \\
productive & 10 & $6 \%$ \\
responsibility & 10 & $6 \%$ \\
tranquil & 8 & $4 \%$ \\
\hline
\end{tabular}

'During an assisted class, I usually feel...'

Most participants do not feel at ease during a class assisted. Instead, they feel, before all, nervous and anxious, beyond feeling observed by others. Despite feeling uncomfortable with the situation, teachers also feel confident, attentive, cheerful and active - teachers love to teach and to practice their profession.

However, although to a lesser degree, teachers also reveal feelings of misunderstanding and frustration, by all that is happening and that involves them, in some cases, leading them to a state of acceptance or resignation (cf. Table 2).

Table 2. 'During an assisted class, I usually feel...'

\begin{tabular}{l|c|c}
\hline Word & Frequency & $\%$ \\
\hline nervous & 80 & $45 \%$ \\
anxious & 69 & $39 \%$ \\
observed & 47 & $27 \%$ \\
confident & 40 & $23 \%$ \\
careful & 33 & $19 \%$ \\
cheerful & 26 & $15 \%$ \\
active & 25 & $14 \%$ \\
unsafe & 22 & $13 \%$ \\
frustrated & 21 & $12 \%$ \\
valued & 20 & $11 \%$ \\
resigned & 16 & $9 \%$ \\
tranquil & 13 & $7 \%$ \\
\hline
\end{tabular}

In what concerns to the representations of pedagogical supervision...

Table 3. Answers to the question, 'Pedagogical supervision makes me think of...'

\begin{tabular}{l|c|c}
\hline Word & Frequency & $\%$ \\
\hline evaluate & 49 & $28 \%$ \\
observer & 40 & $23 \%$ \\
\hline \multicolumn{3}{c}{192}
\end{tabular}




\begin{tabular}{l|c|c}
\hline directing & 34 & $19 \%$ \\
learning & 27 & $15 \%$ \\
cruel & 25 & $14 \%$ \\
share & 22 & $13 \%$ \\
bureaucracy & 22 & $13 \%$ \\
teaching & 22 & $13 \%$ \\
quality & 22 & $13 \%$ \\
resigned & 13 & $7 \%$ \\
frustrated & 13 & $7 \%$ \\
work & 12 & $7 \%$ \\
discipline & 12 & $7 \%$ \\
anxious & 12 & $7 \%$ \\
responsibility & 11 & $6 \%$ \\
confident & 10 & $6 \%$ \\
nervous & 9 & $5 \%$ \\
useless & 9 & $5 \%$ \\
change & 9 & $5 \%$ \\
\hline
\end{tabular}

Most participants feel observed and evaluated when they think about pedagogical supervision (evaluated is referenced for almost 30\% of participants). Simultaneously, teachers feel supported in the process and encouraged to take advantage of this observation to increasingly learn, and develop greater capacity for autonomy and management, in the process of teaching and learning.

To reinforce this ambivalence, we also find the words to share, cruel and bureaucracy, which leads us to think that the pedagogical supervision generates both knowledge and experience, as well as some uncertainty, resignation or sense of injustice, by the process itself, in the face of difficulties and the ratings assigned. Teachers anticipate that with work, discipline and some confidence and responsibility, can overcome the apprehension and anxiety that oversight raises on them, trying to take something from this process that will help them to improve their own performance (cf. Table 3).

'Pedagogical supervision makes me feel...'

Participants say they feel particularly nervous and observed. And this has to do with the observation, by the supervisor. The fact of being alone on a day-to-day with their students, leads the teachers to feel nervous about the presence of a stranger to their everyday life, and which is there to observe them. So teachers also feel a little anxious and often unaccompanied and unprotected, during the process of supervision, in their classes.

Given the success of observation not only depends upon the teachers themselves, and include, in particular, the students (who sometimes do not want to collaborate with teachers, in the teaching-learning process, and thereby they may harm them in their assessment), leads the teachers to feel frustrated and concerned with this procedure, that may become ruthless in his career (cf. Table 4).

Table 4. 'Pedagogical supervision makes me feel...'

\begin{tabular}{l|c|c}
\hline Word & Frequency & $\%$ \\
\hline nervous & 39 & $22 \%$ \\
observed & 38 & $22 \%$ \\
anxious & 26 & $15 \%$ \\
frustrated & 25 & $14 \%$ \\
cruel & 23 & $13 \%$ \\
directed & 21 & $12 \%$ \\
resigned & 20 & $11 \%$ \\
evaluate & 19 & $11 \%$ \\
confident & 19 & $11 \%$ \\
careful & 16 & $9 \%$ \\
active & 16 & $9 \%$ \\
unhappy & 13 & $7 \%$ \\
unsafe & 12 & $7 \%$ \\
\hline
\end{tabular}




\section{Discussion}

Although they play an important role in society, teachers suffer now a strong discreditation by society. The malaise is justified by the difficulty inherent to the profession, for failing to correspond to the expectations or, for having a profession that maybe it was not their first choice.

The fact that today the role of the teacher have lost some prestige and impact on the society in which we live, may also justify this uneasiness in the teaching career (e.g., Handal and Lauvas, 1987; Zeichner, 1993).

The loss of authority, the excessive bureaucracy and lack of interest from students, means that teachers feel that their job is almost impossible.

The sensation of assessment in the course of supervision, generates, especially, negative feelings. There are several important factors that affect the performance of teachers in the classroom, as the number of students, the educational community or geographical location, and these factors are not considered by supervisors, although they are fundamental to achieving quality education. Insecurity and nervousness expressed by teachers, is also related to all that has been debated on the evaluation of teachers and their implications in their career (e.g., Schaffer, 1996; Soveral, 1996). While women show less positive feelings about the way they feel during an assisted class, men denote some contradiction in their feelings (cf. Table 5).

Most participants stated that nowadays, due to the way society is structured on what concerns to the values and habits of the family, the school became the place where students acquire knowledge and at the same time, receive rules, values and references (e.g., Schaffer, 1996; Soveral, 1996).

One of the great difficulties expressed by teachers is the bad education demonstrated by some students, associated with shortage of time to give them knowledge and at the same time, to educate them.

Most teachers represent the pedagogical supervision as a process of evaluation, with lots of bureaucracy and injustice. They have distrust on how the evaluation takes place. They note that the supervision process should be simpler, helping to make the teaching more effective, transparent and more helpful to students, and not to evaluate teachers, dividing them into categories, preventing therefore its progression in terms career.

There is a greater anxiety and nervousness on the part of women than men, which reveals their difficulty differentiating between personal lives and profession, often evidencing their maternal side in the classroom.

Table 5. Synthesis of feelings and emotions, by teaching cycle and gender/sex

\begin{tabular}{|c|c|c|c|c|}
\hline & \multicolumn{2}{|c|}{ teaching cycle } & \multicolumn{2}{|c|}{ gender/sex } \\
\hline & first stage & second stage & Men & Women \\
\hline $\begin{array}{l}\text { 'In the classroom I usually } \\
\text { feel...' }\end{array}$ & $\begin{array}{l}\text { nervous } \\
\text { sensitive } \\
\text { confident }\end{array}$ & $\begin{array}{l}\text { cheerful } \\
\text { anxious } \\
\text { careful }\end{array}$ & $\begin{array}{c}\text { cheerful } \\
\text { tired } \\
\text { accomplished }\end{array}$ & $\begin{array}{l}\text { cheerful } \\
\text { tired } \\
\text { frustrated }\end{array}$ \\
\hline $\begin{array}{l}\text { 'During an assisted class, I } \\
\text { usually feel...' }\end{array}$ & $\begin{array}{l}\text { evaluated } \\
\text { active } \\
\text { nervous }\end{array}$ & $\begin{array}{l}\text { attentive } \\
\text { cheerful }\end{array}$ & $\begin{array}{l}\text { anxious } \\
\text { active } \\
\text { observed }\end{array}$ & $\begin{array}{l}\text { nervous } \\
\text { anxious } \\
\text { observed }\end{array}$ \\
\hline $\begin{array}{l}\text { 'Pedagogical supervision makes } \\
\text { me think/feel...' }\end{array}$ & $\begin{array}{l}\text { learning } \\
\text { quality } \\
\text { active }\end{array}$ & $\begin{array}{l}\text { share } \\
\text { change } \\
\text { directed }\end{array}$ & $\begin{array}{l}\text { directed } \\
\text { observed } \\
\text { share }\end{array}$ & $\begin{array}{c}\text { evaluated } \\
\text { nervous } \\
\text { observed }\end{array}$ \\
\hline
\end{tabular}

In short, and in general, teachers of first stage show greater concern for pedagogical supervision than those of the second stage. This has to do not only with the age difference between students, but also with what is taught in a cycle and the other teaching cycle (cf. Table 5).

Teachers of the 1st stage, due to be just one for each class and according to the greatest number of hours they spent with students, have differing feelings from the teachers of the 2 nd stage in relation to pedagogical supervision.

\section{Conclusions}

Pedagogical supervision is still perceived as something scary, which causes apprehension and confusion. This stems largely from the lack of information about the process, how it should progress, a negative view linked to the evaluation itself - on the prospect that it might serve primarily to generate criticism and reprimands and not exactly to help and contribute to an improvement in professional performance, with the emphasis on the scientific, educational and in a 
better relationship with students (and even with parents).

Today, the efficiency of the school is very often questioned, as well as the quality of teaching, the teacher's role and his performance in the process of teaching and learning. In recent years teachers are having an extra work, with bureaucracy that deprives them of time and forces them to deviate from what is their main function: to educate young people.

The fact that the teaching profession is somehow discredited at this point, together with the lack of interest of many students in school, and disrespect of some of the students for the teachers, does not facilitate the task of the teacher, that, rather than have the opportunity to focus in the transmission of knowledge to their students, has to lose time, and energy, in solving problems in the classroom.

Given the lack of moral values, social and affective from many students, the teachers dedicate and are concerned to be able to create teaching methods that captivate their students. The school should promote the progress of students in a wide range of objectives intellectual, social, moral and emotional. The education system is effective when maximizes the capacity of the school to achieve these results (e.g., Bolivar, 2003; Santos, 1991).

Teaching is not just to transfer knowledge or content, and forming is not an action by which, a creator subject, gives form, style and soul to a body indecisive or accommodated. It is necessary that the student assume itself as the main subject of his training and of the production of knowledge, engaging himself from the start in its construction. Thus, it is up to the teacher to create the possibilities for that to happen (e.g., Freire, 2002).

The way of perceiving the evaluation and supervision, leads teachers to have negative representations of supervision, which may limit and transform, negatively, their daily posture in the classroom.

In terms of gender, women stress more their maternal side, friendly and personalized support to their students, than men. These, usually focus on a professional dimension of teaching, through which students must acquire new skills and competences.

We also found that teachers of the 1st stage feel more responsibility and have greater monitoring of their students, concentrated in doing a good job that allows to provide students with strategies and skills to overcome the difficulties of the academic path, which may be long and complicated. Teachers of the 2 nd stage relate primarily to the importance of sharing knowledge with them, and monitoring them, so that they feel safe and accompanied.

Pedagogical supervision should be seen as an activity support, guidance and regulation, with a very important dimension of training, with a diversity of practices (Sá-Chaves and Alarcão, 2000).

The concept of supervision has followed the evolution of different approaches to education, and streamlined views on everything that involves school. Assuming that the role of the educator is to teach how to think properly (e.g., Freire, 1997), then one of the functions of the supervisor (in teacher training) is precisely to teach how to search, because there is no teaching without research, and there is no research without teaching.

\section{References}

Alarcão, I. (2003). Professores reflexivos em uma escola reflexiva. São Paulo: Cortez.

Allport, G. (1968). The historical background of modern psychology. In G. Lindzey \& E. Aronson (Eds.), The Handbook of Social Psychology (Vol. I). Addison-Wesley.

Amâncio, L. (1994). Masculino e feminino: a construção social da diferença. Porto: Afrontamento.

Amâncio, L. (2003). Género e assimetria simbólica, o lugar da história na psicologia social. In: L. Lima, P. Castro \& M. Garrido (Eds.), Temas e debates em psicologia social. Lisboa: livros Horizonte.

Bidarra, M. G. A. (1986). O estudo das representações sociais: considerações teórico-conceptuais e metodológicas. Revista Portuguesa de Pedagogia, XX, 369-390.

Bolívar, A. (2003). Como melhorar as escolas. Porto: Edições ASA.

Freire, P. (1997). Política e educação. São Paulo: Cortez, p. 42.

Freire, P. (2002). Pedagogia da Autonomia: Saberes necessários à prática educativa. São Paulo: Edição paz e terra (24aedição).

Handal, G. \& Lauvas, P. (1987). Promoting reflexive teaching: Supervision in action. Milton Keynes: Open University Press.

Mintzberg, H. (1995). Estrutura e Dinâmica das Organizações. Lisboa: Publicações Dom Quixote.

Oliveira, A. (2011). O Desafio da Vida. Lisboa: Coisas de Ler.

Oliveira, A. (2008). O Desafio da Morte. Lisboa: Âncora editora.

Oliveira, A. (2008). Ilusões na Idade das Emoções - representações sociais da morte, do suicídio e da música na adolescência. Lisboa: F.C.T./Fundação Calouste Gulbenkian.

Oliveira, A. \& Amâncio, L. (2005). A análise factorial de correspondências no estudo das representações sociais - as representações sociais da morte e do suicídio na adolescência. In A. Moreira, B. Camargo, J. Jesuíno \& S. Nóbrega (Eds.), Perspectivas teórico-metodológicas em representações sociais. Paraíba: Ed. Universitária UFPB, (Cap. 10) pp. 323-362.

Pinho, L. (1993). Humanizar a Escola. Comunicação, representações sociais e sucesso escolar. Cadernos CIDInE, 6, 5-10. 
Sá-Chaves, I. \& Alarcão, I. (2000). Supervisão de professores e desenvolvimento humano: uma perspectiva ecológica. In: Sá-Chaves, I.

(Eds.), Formação, conhecimento e supervisão - contributos nas áreas de formação de professores e de outros profissionais. Estudos temáticos, 1. Aveiro: Universidade de Aveiro.

Santos, J. (1991). Ensaios sobre a educação I, a criança quem é? (2ª edição). Lisboa: Livros Horizonte.

Schaffer, H. (1996). Desenvolvimento social da criança. Lisboa: Instituto Piaget.

Simões, C. M. \& Ralha-Simões, H. (1997). Maturidade Pessoal, Dimensões da Competência e Desempenho Profissional. In I. SáChaves (Eds.), Percursos de Formação e Desenvolvimento Profissional (pág.37-57). Porto: Porto Editora.

Soczka, L. (1988). Representações sociais, relações intergrupos e identidades profissionais dos psicólogos. Psicologia, 2, 253-275.

Soveral, M. (1996). O sujeito em formação, o desenvolvimento do aluno/pessoa no contexto da relação pedagógica. Tese de mestrado não publicada. Lisboa: Faculdade de Ciências e Tecnologia da Universidade Nova de Lisboa.

Zeichner, K. (1993). A Formação Reflexiva de Professores: Ideias e Práticas. Lisboa: Educa. 